\title{
THE MERITS AND DRAWBACKS OF ELECTRONIC JOURNALS: A RESEARCH SURVEY OF AEROSPACE SCIENTISTS AND ENGINEERS OF BANGALORE
}

\author{
R Guruprasad ${ }^{1 *}$ \\ ${ }^{*}$ Scientist, Knowledge and Technology Management Division, CSIR-National Aerospace Laboratories, Bangalore. \\ E-mail: gprasad@nal.res.in / gprasad61@gmail.com
}

*Corresponding Author: -

E-mail: gprasad@nal.res.in / gprasad61@gmail.com

\begin{abstract}
: -
Today, scientific journals undoubtedly represent the most vital means for disseminating research findings. Often, the research challenges common assumptions and/or the research data presented in the published scientific literature in order to gain a clearer understanding of the facts and findings. Depending upon the policies of a given journal, articles may include reports of original research, re-analyses of others' research, reviews of the literature in a specific area, proposals of new but untested theories, or opinion pieces. One can also say that, journals are fundamental to formal scholarly communication. It is also observed that for more than three centuries, scholarly journals have played a pivotal role in the creation and dissemination of knowledge by serving as the primary medium of scholarly communication. This has however remained unchanged in form and function over its lifetime. It is now very clear that science as we know it is scarcely imaginable without the scholarly journal [1, 2].

A research study was undertaken to study the 'Advantages and Disadvantages of Electronic Journals' The geographic boundary of this research study consisted of 16 prominent aerospace organizations of Bangalore. The age-group of this study was between 21-60 years. The broad areas of specialization of the Aerospace Scientists and Engineers have been classified into (a) Thermal and Fluid Sciences, (b) Avionics, Guidance and Control, (c) Aerospace Structures and Allied Mechanical Sciences, (d) Materials and Metallurgy, (e) Flight Operations and other Allied Disciplines, and ( $f)$ General Engineering and Support Sciences. The major conclusions of this study are: (a) Analysis of Variance (ANOVA) was applied for testing the significant difference among the 16 mean scores attained from the scientists and engineers of the aerospace organizations for 'Advantages of Use of e-Journals'. It is observed that all the 16 aerospace organizations show a significant difference $(P<0.05)$ in their mean scores viz., 'Current / Up to Date Information', Ease of Search', Ease of Browsing', Multi-User Access, Fast Access, 'Ability to Download', '24 Hour Access', 'Available Before Print', 'Search-ability of Databases among Journals', 'e-Back Volumes are Available', 'Non-Availability of Print Volumes', 'Easy Backup Availability' and 'Multiple e-Choice of Formats (PDF, RTF, DOC and HTML)'. (b) Analysis of Variance (ANOVA) was applied for testing the significant difference among the 16 mean scores attained from the scientists and engineers of the aerospace organizations for 'Disadvantages of e-Journals'. It is observed that all the 16 aerospace organizations show a significant difference $(P<0.05)$ in their mean scores viz., 'Slow Downloads', 'Additional Payment', 'Problems with Print Facilities in Databases', 'Dependence on Connectivity', 'Quality of Print Images is Low' and 'It is Difficult to Read on Screen, except for 'Frames', 'Navigation', 'Insecurity of Preservation' and 'Accessibility'
\end{abstract}

\section{(우 (\$) (1)}




\section{INTRODUCTION}

The advent of the electronic journal has truly been called "the grandest revolution in the capture and dissemination of emerging academic knowledge”, [3, 4]. Originally, scholarly journals were published by learned societies. In fact, due to the tightly knit collaboration among scientists and learned societies, these scholarly journals were given the name "Circle of Gifts", whereby authors contributed their works for publication in order to disseminate their ideas, and the scholarly society's compiled journals for distribution to scholars who then responded with contributions of their own. Today, commercial publishers are largely responsible for a wide number of scholarly journals, which have gained prominence especially since the middle of the 20th century.

The years following the World War-II, and with the post/war industrial boom in Europe and Japan together with the Cold War-driven scientific developments in the US and the USSR - saw the growing demand for research in a number of fields. New disciplines were imprinted out of the existing knowledge schema and technological advances permitted scientists to branch into new fields. At the same time, a great deal of pressure was exerted on the scholars by their own institutions, which forced them to produce more published works under the well-known hymn of "Publish or Perish". This resulted in even more articles seeking publishers. For instance, the American Institute of Physics had recorded a $100 \%$ increase in the number of articles submitted to it in the past 20 years. The existing publishing entities in the post war period - mainly societies and universities - were unable to pick up the overflow caused by both userbased and author-based demand for new titles, and so commercial publishers stepped in to fill the void.

The exponential growth of electronic journals began when libraries began having access to the WWW in the mid-1990s. In view of the paradigm shift from paper to digital, it has affected the traditional alignment and role of the primary "stakeholders" - mainly authors, publishers, universities and libraries. Scholarly journals contain a large percentage of articles based on original scholarship or research. Their contents are submitted by the authors, rather than being predetermined by the editor $[\mathbf{5}, \mathbf{6}]$.

Further evidence of academic acceptance of electronic journals has been found in the fact that so many prestigious institutions have signed the Budapest Open Access Initiative (BOAI), and have become members of the Scholarly Publishing and Academic Resources Coalition (SPARC). Over 200 prominent organizations and universities have signed in support of BOAI which has as its goal 'the world-wide electronic distribution of the peer-reviewed journal literature and completely free and unrestricted access to it by all scientists, scholars, teachers, students, and other curious minds'. The framers of the initiative saw new technology as the means for accomplishing this goal, [7, 8, 9].

Finally, from the scholar/author's point of view, the most tangible benefits of electronic publications are speed and freedom from constraints of journal length. Neither publication delays are no longer necessary, nor do worthy articles need to be eliminated from journals due to space restrictions.

\section{Review of Literature}

These authors opine that scholarly communication can take place via a number of documentary genres (as well as conversational genres) including letters, memos, conference papers, technical reports, dissertations, primary articles, review essays, monographs, and edited books. However, the most important scholarly literature is composed of articles (usually published in journals or disseminated at conferences) and books. The study also emphasizes the point that the vast majority of attempts to use the Internet in enhancing scholarly communication have focused on articles. In addition, most of the research about scholars' experiences with electronic media has emphasized articles; especially those packaged as peer-reviewed e-journals [10].

This research study provides some insight into the diffusion and adoption of electronic publishing as a technological innovation in academia. The respondents in this survey gave the greatest importance to the role of peer reviewed publications to the tenure, promotion, and merit review process. Hence, the long-term growth and sustainability of electronic journals must more directly address this issue, [11].

This study tracked the information seeking and reading patterns of science, technology, medical and social science faculty members from 1977 to the present, to examine how faculty members locate, obtain, read, and use scholarly articles and how this has changed with the widespread availability of electronic journals and journal alternatives. The study also revealed that electronic articles now account for the majority of readings, though most readings are still printed on paper for final reading. Also, scientists reported reading a higher proportion of older articles from a wider range of journal titles and more articles from library e-collections. Articles are read for many purposes and readings are valuable to those purposes, [12].

Scholarly communication through electronic resources has attracted considerable attention. Electronic journals, among others, are particularly important. Several statistical reports have indicated an increase in the number of electronic journals, [13]. The authors also inter-alia quote Morioka, whose study revealed that the proportion of journals in electronic version on physics increased from about $50 \%$ in 1998 to more than $80 \%$ in 2002, [14].

In this study, the author examines the role of different players in the total gamut of the scholarly communication 
process such as: authors, commercial publishers, libraries, universities, and learned societies, their problems and efforts in meeting the new challenges brought in by the Internet. This study also explores the need for adopting electronic media for scholarly communication in place of printed journals considering the advantages such as accessibility, speed, cost and acceptance by the academic and research community, [15].

In his book, the author mentions that the availability of international computer networks and the widespread proliferation of computer-mediated communication within the academy signifies a radical break with forms of scholarly communication of the past and promises that a diverse set of electronic research, educational, and publication practices will comprise scholarship in the twenty-first century, [16].

In this study it is seen that the use of electronic media to support scientific communication is one of the major shifts in the practice of science in this era. It is observed that since 1990, scientists, publishers, and librarians have initiated thousands of electronic publishing ventures, including new electronic journals and disciplinary databases. Today, Internet is the primary medium of this scholarly and scientific communication. Most importantly, scholarly community converges on a stable set of electronic forums, such as "preprint" servers, discussion lists, and electronic journals. Also due to the availability of variety of e-media initiatives, reflects a creative period in scientific communication, and this, in itself, is a good thing [17].

The author inter-alia quotes Kling et al. and Taubes who point out that electronic journals offer opportunities for innovations or enhancements in content. A recent issue of Science notes interesting ways that particular journals add hyperlinks to video and audio features. Other e-journals augment or link individual articles to relevant discussion forums, related articles, or notification and alerting services. For example, The Journal of Current Clinical Trials, and Science Online itself create hypertext links between related articles and letters to the editor, [18, 19, 20].

\section{CSIR-National Aerospace Laboratories, Bangalore and Allied Aerospace Organizations in Bangalore: The Scope of the PresentStudy}

The National Aerospace Laboratories is India's premier civil aviation R\&D aerospace research organization in the country. Its main mandate is the 'Development of aerospace technologies with a strong science content, design and build small and medium - sized civil aircraft, and support all national aerospace programmes. NAL is also required 'to use its aerospace technology base for general industrial applications'. 'Technology' would be its core engine-driver for the future. NAL is also best known for its main sophisticated aerospace R\&D testing facilities which are not only unique for this country but also comparable to similar facilities elsewhere in the world.

Sixteen prominent aerospace organizations of Bangalore were selected for this research study (See Table 1), and many of these aerospace organizations come under the broad umbrella of (i) Council of Scientific and Industrial Research (CSIR), (ii) Defense Research and Development Organizations (DRDO), (iii) The Indian Air Force (IAF), (iv) Educational Institutions like IISc, and (v) Major public sector undertakings and (vi) The Department of Space. All of them in their own way have significantly contributed to a large number of Indian aerospace programmes.

\section{Null Hypotheses}

- There is no significant difference in the mean scores of 'Advantages / Disadvantages of e-Journals' among the aerospace scientists and engineers of Bangalore.

\section{Objectives of the Study}

- To determine the frequency of 'Advantages / Disadvantages of e-Journals' among the aerospace scientists and engineers of Bangalore

- To ascertain whether the percentage of preference of 'Advantages / Disadvantages of e-Journals' by the aerospace engineers and scientists are approximately the same.

\section{Materials and Methods}

The present study is restricted to the selected 16 prominent aerospace organizations in Bangalore. A total number of 650 survey questionnaires were distributed amongst the aerospace scientists and engineers belonging to these 16 aerospace organizations. A total number of 612 questionnaires were received back finally $583(89.7 \%)$ were selected for the study which were found suitable for the study. A survey questionnaire has been used to conduct this research study. The total population size of this research study is restricted to the 1220 aerospace scientists and engineers in Bangalore. The distribution of Source Data is indicated in Table 1. The investigator also divided the whole population of the study into two major categories: namely, aerospace scientists and engineers. It may be seen from Table 2, that out of 583 respondents, $295(50.6 \%)$ are aerospace scientists and the remaining $288(49.4 \%)$ are aerospace engineers. The questionnaire distribution pattern used in the Survey is indicated in Table $3 a, b$. And, finally the 'Advantages and Disadvantages of e-Journals' are illustrated in Table 4a,b, with the necessary statistical inferences. Random sampling technique has been used for selection of the sample size. 


\section{Results and Discussion}

\section{Summary of Total Scores on Advantages of Use of e-Journals}

The summary of total scores obtained with regard to the 'Advantages of Use of e-Journals' is as follows. The highest mean score of 2.90(CV=47.45) is taken up for 'Current / up to date information'. This is followed by 'Ease of Search' which gets a mean score of $2.89(\mathrm{CV}=47.11)$. The next highest mean score of $2.82(\mathrm{CV}=48.18)$ is taken up for 'Ease of Browsing'. This is followed by a mean score of $2.67(\mathrm{CV}=51.64)$ which gets occupied for '24 Hour Access'. 'Ability to Download' gets the next highest mean score of $2.66(\mathrm{CV}=50.51)$. This is followed by 'Multi-user access, fast access' which occupies a mean score of $2.55(\mathrm{CV}=54.65)$. A mean score of $2.42(\mathrm{CV}=58.81)$ is represented by 'Available Before Print'. 'Searchability of databases among Journals' represents itself with the next highest mean score of 2.33(CV=61.89). The option 'Multiple choice of formats (PDF, RTF, DOC and HTML) occupy the next place with a mean score of 2.32( $\mathrm{CV}=63.04)$. A mean score of $2.23(\mathrm{CV}=64.32)$ is represented by the option 'Easy Backup Availability'. A low mean score of $2.19(\mathrm{CV}=64.68)$ is represented by 'e-Back Volumes are Available'. Finally, the lowest mean score is occupied by 'Non-availability of Print Volumes' scoring 1.97 and accruing a CV value of 71.65.

Analysis of Variance (ANOVA) was applied for testing the significant difference among the 16 mean scores attained from the scientists and engineers of the aerospace organizations for 'Advantages of Use of e-Journals'. It is observed that all the 16 aerospace organizations show a significant difference $(\mathrm{P}<0.05)$ in their mean scores viz., 'Current / Up to Date Information', Ease of Search', Ease of Browsing', Multi-User Access, Fast Access, 'Ability to Download', '24 Hour Access', 'Available Before Print', 'Searchability of Databases among Journals', 'e-Back Volumes are Available', 'NonAvailability of Print Volumes', 'Easy Backup Availability' and 'Multiple e-Choice of Formats (PDF, RTF, DOC and HTML)'

\section{Summary of Total Scores on Disadvantages of Use of e-Journals}

The summary of total mean scores obtained with regard to the 'Disadvantages of Use of e-Journals' is as follows. The highest mean score of 2.07(CV=65.59) is taken up by the option, 'Slow Download'. This is followed by the option 'Additional Payment' which reflects a mean value 2.02(CV=73.65). The next highest mean score of $1.97(\mathrm{CV}=69.83)$ is taken up for the option 'It is Difficult to Read on Screen'. This is followed by the option 'Dependence on Connectivity' which gets a mean score of $1.93(\mathrm{CV}=71.50)$. This is followed by the mean score of $1.81(\mathrm{CV}=71.08)$ for the option 'Accessibility'. A mean value of 1.74(CV=72.58) is taken up for the option 'Quality of Print Images'. This is followed by the option 'Problems with Print Facilities in Databases' which gets a mean score of 1.67(CV=77.21). The next option which gets the next highest mean score of $1.64(\mathrm{CV}=76.43)$ gets reflected for 'Navigation'. A mean score of $1.63(\mathrm{CV}=81.10)$ is represented by the option 'Insecurity of Preservation'. Finally, the option which gets the lowest mean score of $1.60(\mathrm{CV}=79.570)$ is represented for the option 'Frames'.

Analysis of Variance (ANOVA) was applied for testing the significant difference among the 16 mean scores attained from the scientists and engineers of the aerospace organizations for 'Disadvantages of e-Journals'. It is observed that all the 16 aerospace organizations show a significant difference $(\mathrm{P}<0.05)$ in their mean scores viz., 'Slow Downloads', 'Additional Payment', 'Problems with Print Facilities in Databases', 'Dependence on Connectivity', 'Quality of Print Images is Low' and 'It is Difficult to Read on Screen, except for 'Frames', 'Navigation', 'Insecurity of Preservation' and 'Accessibility'

\section{Conclusions}

The main conclusions of this research study that the authors would like to present are:

- Analysis of Variance (ANOVA) was applied for testing the significant difference among the 16 mean scores attained from the scientists and engineers of the aerospace organizations for 'Advantages of Use of e-Journals'. It is observed that all the 16 aerospace organizations show a significant difference $(\mathrm{P}<0.05)$ in their mean scores viz., 'Current / Up to Date Information', Ease of Search', Ease of Browsing', Multi-User Access, Fast Access, 'Ability to Download', '24 Hour Access', 'Available Before Print', 'Searchability of Databases among Journals', 'e-Back Volumes are Available', 'Non- Availability of Print Volumes', 'Easy Backup Availability' and 'Multiple e-Choice of Formats (PDF, RTF, DOC and HTML)'

- This also implies that the percentage of preference of 'Advantages of use of E-Journals' by the aerospace engineers and scientists are not approximately the same.

- Analysis of Variance (ANOVA) was applied for testing the significant difference among the 16 mean scores attained from the scientists and engineers of the aerospace organizations for 'Disadvantages of e-Journals'. It is observed that all the 16 aerospace organizations show a significant difference $(\mathrm{P}<0.05)$ in their mean scores viz., 'Slow Downloads', 'Additional Payment', 'Problems with Print Facilities in Databases', 'Dependence on Connectivity', 'Quality of Print Images is Low', 'It is Difficult to Read on Screen, except for 'Frames', 'Navigation', 'Insecurity of Preservation' and 'Accessibility'

- This also implies that the percentage of preference of 'Disadvantages of use of E-Journals' by the aerospace engineers and scientists are not approximately the same, except for 'Frames', 'Navigation', 'Insecurity of Preservation' and 'Accessibility' 


\section{Acknowledgments}

The authors would like to thank Director, NAL and Head, KTMD for their support.

10. References

[1]. 'What are Scientific Journals' (2000), American Psychological Association, http://www.apa.org/about/gr/issues/review/journal-fact.aspx

[2].Harter, P.S. and Kim, H.K. (1997), 'Electronic Journals and Scholarly Communication: A Citation and Reference Study', The Journal of Electronic Publishing, 3(2), DOI: http://dx.doi.org/10.3998/3336451.0003.212

[3].Wills, G. (1996). 'Embracing Electronic publishing'. Internet Research: Networking Applications and Policy, 6, 7790.

[4].Wills, M. \& Wills, G. (1996). 'The Ins and Outs of Electronic Publishing. Internet Research, 6, 10-21

[5].Keefer, A., (2001), 'Electronic Journals, Scholarly Communication and Libraries', biblioteconomia documentation, 6.

[6].James, A., (2000). 'Physicists in the New Era of Electronic Publishing'. Physics today, 53(8)1, 35-38.

[7].(http://www.soros.org/openaccess/view.cfm).

[8].http://www.arl.org/sparc/core/index.asp?page=b1.

[9].Budapest Open Access Initative, October 19, 2003.

[10]. Kling, R., and Callahan, E., (2003), 'Electronic Journals, The Internet and Scholarly Communication', Annual Review of Information Science and Technology, 127-177.

[11]. Speier, C., Palmer, J., Wren, D., and Hahn, S., (1999), 'Faculty Perceptions of Electronic Journals as Scholarly Communication: A Question of Prestige and Legitimacy', Journal of the American Society for Information Science, 50(6).

[12]. Tenopir, C., King, D.W., Edwards, S. and Wu, L., (2009), 'Electronic Journals and Changes in Scholarly Article Seeking and Reading Patterns', Aslib Proceedings, 61(1), 5 - 32.

[13]. Kurata, K., et al., (2007), 'Electronic Journals and their unbundled functions in Scholarly Communication: Views and Utilization by Scientific, Technological and Medical Researchers in Japan, Information and Processing Management, 43, 1402-1415. (Elsevier Science Direct).

[14]. Morioka, M. (2005), 'Development and Trends in Electronic Journals: Dissemination of Electronic versions of Print Journals from 1998 to 2002, Library and Information Science, 53, 19-36 (in Japanese).

[15]. Rao, M.K., (2001), 'Scholarly Communication and Electronic Journals: Issues and Prospects for Academic and Research Libraries, Library Review, 50(4), 169-175.

[16]. Harrison, T.M. and Stephen, T. (1996), 'Computer Networking and Scholarly Communication in the Twenty-FirstCentury', State University of New york Press.

[17]. Kling, R., and McKim, G., (2000), 'Not Just a Matter of Time: Field Differences and the Shaping of Electronic Media in Supporting Scientific Communication'.

[18]. Lizbeth, A.L., (1996), 'Scholarly Publication and Electronic Publication: Implications for Research, Advancement and Promotion'. Untangling the Web, Educational Resources Information Center, U.S. Department of Education.

[19]. Kling, Rob, Covi, Lisa. (1995). 'Electronic Journals and Legitimate Media in the Systems of Scholarly Communication'. Information Society. 11(4), 261-271.

[20]. Taubes, G., (1996b), 'Science Journals Go Wired', Science 271(9), 764-766.

Tables and Figures

Table-1: Distribution of Source Data (Sample Size)

\begin{tabular}{|l|l|l|l|l|}
\hline Sl.No. & Organizations & $\begin{array}{l}\text { No. of } \\
\text { Questionnaires } \\
\text { distributed }\end{array}$ & $\begin{array}{l}\text { No. } \\
\text { of } \\
\text { Questionnaires } \\
\text { received }\end{array}$ & $\begin{array}{l}\text { No. of usable } \\
\text { questionnaires } \\
\text { usable }\end{array}$ \\
\hline $\mathbf{1 .}$ & ADA & 67 & 63 & 58 \\
\hline $\mathbf{2 .}$ & AFTC & 19 & 16 & 15 \\
\hline $\mathbf{3 .}$ & ADE & 14 & 12 & 12 \\
\hline $\mathbf{4 .}$ & ASTE & 33 & 30 & 29 \\
\hline $\mathbf{5 .}$ & CABS & 16 & 15 & 14 \\
\hline $\mathbf{6 .}$ & CEMILAC & 33 & 30 & 29 \\
\hline $\mathbf{7 .}$ & C-MMACS & 8 & 6 & 6 \\
\hline $\mathbf{8 .}$ & DARE & 11 & 9 & 9 \\
\hline $\mathbf{9 .}$ & LRDE & 5 & 3 & 2 \\
\hline $\mathbf{1 0 .}$ & GTRE & 24 & 22 & 21 \\
\hline $\mathbf{1 1 .}$ & HAL & 144 & 140 & 134 \\
\hline $\mathbf{1 2 .}$ & IAM & 40 & 36 & 33 \\
\hline $\mathbf{1 3 .}$ & ISRO-ISTRAC & 25 & 24 & 22 \\
\hline $\mathbf{1 4 .}$ & IISc & 38 & 37 & 34 \\
\hline $\mathbf{1 5 .}$ & JNCASR & 5 & 3 & 1 \\
\hline $\mathbf{1 6 .}$ & NAL & 168 & 166 & 164 \\
\hline Total & & $\mathbf{6 5 0}$ & $\mathbf{6 1 2}$ & $\mathbf{5 8 3 ( 8 9 . 7 \% )}$ \\
\hline
\end{tabular}


Geographical Boundary of the Study (16 Prominent Aerospace Organizations of Bangalore, INDIA). Key: ADA=Aeronautical Development Agency, AFTC=Air Force Technical College, ADE=Aeronautical Development Establishment, ASTE=Aircraft Systems Testing Establishment, CABS=Centre for Airborne Systems, CEMILAC $=$ Centre for Military Airworthiness and Certification, C-MMACS=Centre for Mathematical Modeling and Computer Simulation, DARE=Defense Avionics Research Establishment, LRDE=Electronics and Radar Development Establishment, GTRE=Gas Turbine Research Establishment, HAL=Hindustan Aeronautics Limited, IAM=Institute of Aerospace Medicine, ISRO-ISTRAC=Indian Space Research Organization, IISc=Indian Institute of Science, JNCASR=Jawaharlal Nehru Centre for Advanced Scientific Research, NAL=National Aerospace Laboratories.

Table-2: Profile of the Respondents (Category-Wise Distribution)

\begin{tabular}{|c|c|c|c|c|c|}
\hline \multirow[b]{3}{*}{ Sl. No. } & \multirow[b]{3}{*}{ Organizations } & \multirow{2}{*}{\multicolumn{2}{|c|}{ Categories }} & \multirow{3}{*}{$\begin{array}{l}\text { Organization } \\
\text { Wise, } \\
\text { Total No. of } \\
\text { Respondents }\end{array}$} & \multirow[b]{3}{*}{$\begin{array}{l}\text { of Total } \\
\text { Sample }\end{array}$} \\
\hline & & & & & \\
\hline & & $\begin{array}{l}\text { Aerospace } \\
\text { Scientist }\end{array}$ & $\begin{array}{l}\text { Aerospace } \\
\text { Engineer }\end{array}$ & & \\
\hline 1 & ADA & 39 & 19 & 58 & 9.9 \\
\hline 2 & AFTC & 0 & 15 & 15 & 2.6 \\
\hline 3 & ADE & 12 & 0 & 12 & 2.1 \\
\hline 4 & ASTE & 2 & 27 & 29 & 5.0 \\
\hline 5 & CABS & 13 & 1 & 14 & 2.4 \\
\hline 6 & CEMILAC & 26 & 3 & 29 & 5.0 \\
\hline 7 & C-MMACS & 2 & 4 & 6 & 1.0 \\
\hline 8 & DARE & 7 & 2 & 9 & 1.5 \\
\hline \multirow[b]{2}{*}{ SI. No. } & \multirow[b]{2}{*}{ Organizations } & \multicolumn{2}{|c|}{ Categories } & \multirow[b]{2}{*}{$\begin{array}{l}\text { Organization } \\
\text { Wise, } \\
\text { Total No. of } \\
\text { Respondents }\end{array}$} & \multirow[b]{2}{*}{$\begin{array}{l}\text { pof Total } \\
\text { Sample }\end{array}$} \\
\hline & & $\begin{array}{l}\text { lerospace } \\
\text { Scientist }\end{array}$ & $\begin{array}{l}\text { Aerospace } \\
\text { Engineer }\end{array}$ & & \\
\hline 9 & LRDE & 2 & 0 & 2 & 0.3 \\
\hline 10 & GTRE & 12 & 9 & 21 & 3.6 \\
\hline 11 & HAL & 3 & 131 & 134 & 23.0 \\
\hline 12 & IAM & 30 & 3 & 33 & 5.7 \\
\hline 13 & ISRO-ISTRAC & 5 & 17 & 22 & 3.8 \\
\hline 14 & IISc & 21 & 13 & 34 & 5.8 \\
\hline 15 & JNCASR & 1 & 0 & 1 & 0.2 \\
\hline 16 & NAL & 120 & 44 & 164 & 28.1 \\
\hline \multicolumn{2}{|c|}{\begin{tabular}{|l|} 
Total for all \\
Organizations
\end{tabular}} & 295 & 288 & 583 & \\
\hline \multicolumn{2}{|c|}{$\begin{array}{l}\text { Percent for all } \\
\text { Organizations }\end{array}$} & $(50.6)$ & $(49.4)$ & $(\mathbf{1 0 0 . 0 )}$ & 100.0 \\
\hline \multicolumn{2}{|c|}{ Chi-Square } & \multicolumn{4}{|c|}{ 278.811 } \\
\hline \multicolumn{2}{|c|}{ P Value } & \multicolumn{4}{|c|}{0.000} \\
\hline
\end{tabular}

(Numbers in brackets indicate percentages)

Table - 3(a): Sample Questionnaire: Please mark the Advantages of electronic journals use?

4 - to a great exent, 3 - to moderate extent, 2 - to a little extent, 1 - not at all, 0 - cannot say

\begin{tabular}{|c|c|c|c|c|c|}
\hline$(1)$ & Current / upto date information & 4 & 3 & 2 & \begin{tabular}{l|l}
1 & 0 \\
\end{tabular} \\
\hline$(2)$ & Ease of search & 4 & 3 & 2 & \begin{tabular}{l|l}
1 & 0 \\
\end{tabular} \\
\hline (3) & Ease of browsing & 4 & 3 & 2 & \begin{tabular}{l|l}
1 & 0 \\
\end{tabular} \\
\hline (4) & Multi user access, fast access & 4 & 3 & 2 & \begin{tabular}{l|l}
1 & 0
\end{tabular} \\
\hline$(5)$ & Ability to download & 4 & 3 & 2 & \begin{tabular}{l|l}
1 & 0 \\
\end{tabular} \\
\hline$(6)$ & 24 hour access & 4 & 3 & 2 & \begin{tabular}{l|l}
1 & 0 \\
\end{tabular} \\
\hline (7) & Available before Print & 4 & 3 & 2 & \begin{tabular}{l|l}
1 & 0 \\
\end{tabular} \\
\hline$(8)$ & Searchability of databases among Journals & 4 & 3 & 2 & \begin{tabular}{l|l|l|l}
1 & 0 \\
\end{tabular} \\
\hline (9) & E-back volumes are available & 4 & 3 & 2 & \begin{tabular}{l|l}
1 & 0 \\
\end{tabular} \\
\hline$(10)$ & Non-availability of print volumes & 4 & 3 & 2 & \begin{tabular}{l|l}
1 & 0 \\
\end{tabular} \\
\hline$(11)$ & Easy backup availability & 4 & 3 & 2 & \begin{tabular}{l|l|l|l}
1 & 0 \\
\end{tabular} \\
\hline (12) & Multiple choice of formats (PDF, RTF, DOC and HTML & 4 & 3 & 2 & \begin{tabular}{l|l|l}
1 & 0 \\
\end{tabular} \\
\hline
\end{tabular}


Table - 3(b) Sample Questionnaire: Please mark the Disadvantages of electronic journals use? 4 - to a great exent, 3 - to moderate extent, 2 - to a little extent, 1 - not at all, 0 - cannot say

\begin{tabular}{|l|l|l|l|l|l|l|}
\hline$(1)$ & Slow Download & $\mathbf{4}$ & $\mathbf{3}$ & $\mathbf{2}$ & $\mathbf{1}$ & $\mathbf{0}$ \\
\hline$(2)$ & Frames & $\mathbf{4}$ & $\mathbf{3}$ & $\mathbf{2}$ & $\mathbf{1}$ & $\mathbf{0}$ \\
\hline$(3)$ & Navigation & $\mathbf{4}$ & $\mathbf{3}$ & $\mathbf{2}$ & $\mathbf{1}$ & $\mathbf{0}$ \\
\hline$(4)$ & Additional Payment & $\mathbf{4}$ & $\mathbf{3}$ & $\mathbf{2}$ & $\mathbf{1}$ & $\mathbf{0}$ \\
\hline$(5)$ & $\begin{array}{l}\text { Problems with print facilities in } \\
\text { databases }\end{array}$ & $\mathbf{4}$ & $\mathbf{3}$ & $\mathbf{2}$ & $\mathbf{1}$ & $\mathbf{0}$ \\
\hline$(6)$ & Insecurity of preservation & & & & & \\
\hline$(7)$ & Dependence on connectivity & $\mathbf{4}$ & $\mathbf{3}$ & $\mathbf{2}$ & $\mathbf{1}$ & $\mathbf{0}$ \\
\hline$(8)$ & Quality of print images is low & $\mathbf{4}$ & $\mathbf{3}$ & $\mathbf{2}$ & $\mathbf{1}$ & $\mathbf{0}$ \\
\hline$(9)$ & It is difficult to read on screen & $\mathbf{4}$ & $\mathbf{3}$ & $\mathbf{2}$ & $\mathbf{1}$ & $\mathbf{0}$ \\
\hline$(10)$ & Accessibility & $\mathbf{4}$ & $\mathbf{3}$ & $\mathbf{2}$ & $\mathbf{1}$ & $\mathbf{0}$ \\
\hline
\end{tabular}

Table - 4(a) : Advantages of Use of e-Journals

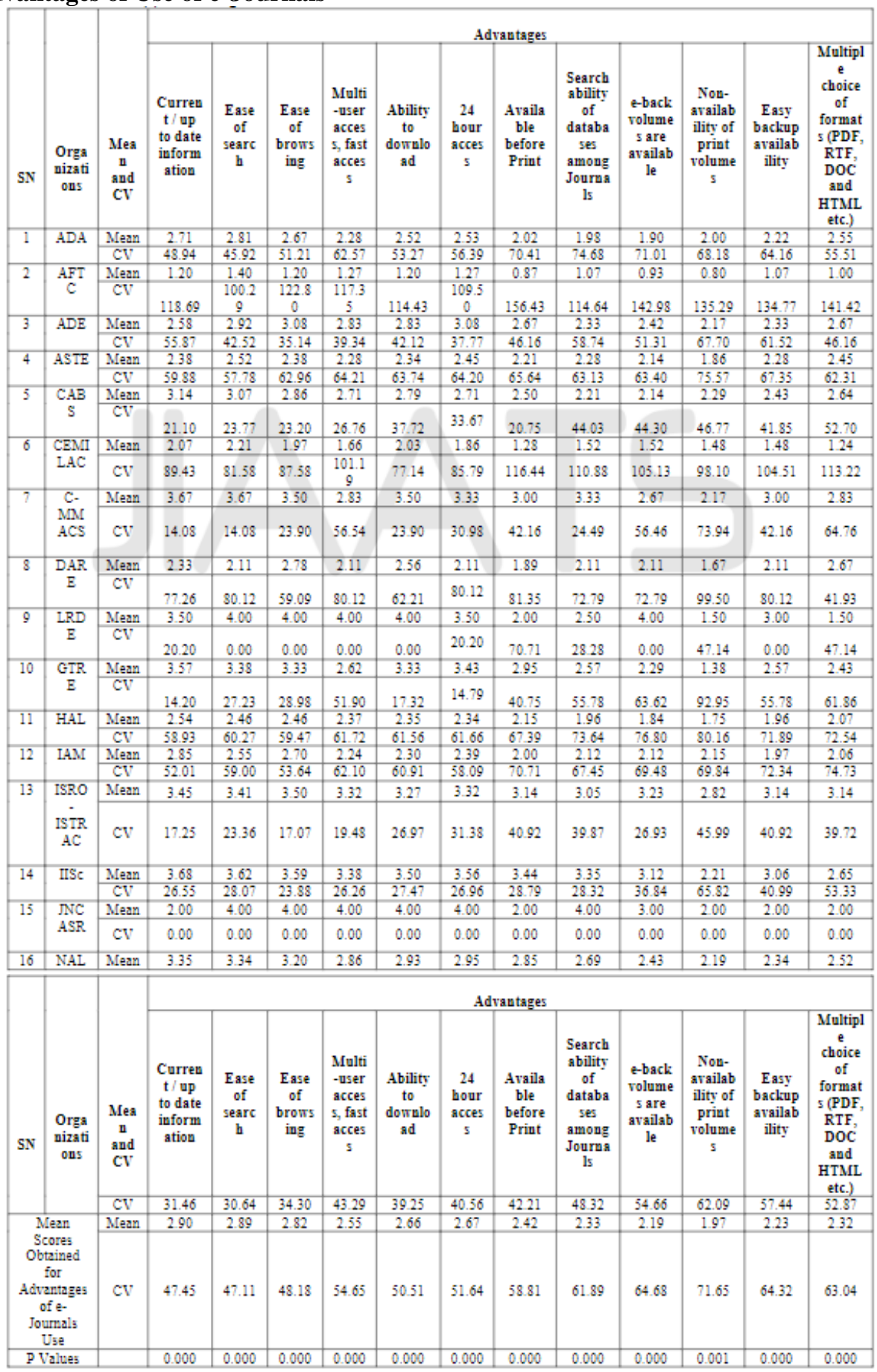


Table - 4(b) : Disadvantages of Use of e-Journals

\begin{tabular}{|c|c|c|c|c|c|c|c|c|c|c|c|c|}
\hline \multirow[b]{2}{*}{$\mathbf{S} \mathbf{N}$} & \multirow[b]{2}{*}{$\begin{array}{c}\text { Organ } \\
\text { ization } \\
\mathrm{s}\end{array}$} & \multirow[b]{2}{*}{$\begin{array}{l}\text { lean } \\
\text { and } \\
\text { CV }\end{array}$} & \multicolumn{10}{|c|}{ Disadvantages } \\
\hline & & & $\begin{array}{l}\text { Slow } \\
\text { downl } \\
\text { oad }\end{array}$ & imes & $\begin{array}{l}\text { Navig } \\
\text { ation }\end{array}$ & $\begin{array}{c}\text { Additio } \\
\text { nal } \\
\text { Paymen } \\
t\end{array}$ & \begin{tabular}{|c|} 
Proble \\
ms \\
with \\
print \\
faciliti \\
es in \\
databa \\
ses \\
\end{tabular} & $\begin{array}{l}\text { Insecu } \\
\text { rity of } \\
\text { Preser } \\
\text { vation }\end{array}$ & $\begin{array}{c}\text { Depen } \\
\text { dence } \\
\text { on } \\
\text { connec } \\
\text { tivity }\end{array}$ & $\begin{array}{c}\text { Qualit } \\
\text { y of } \\
\text { print } \\
\text { images } \\
\text { is low }\end{array}$ & $\begin{array}{c}\text { It is } \\
\text { difficul } \\
t \text { to } \\
\text { read } \\
\text { on } \\
\text { screen }\end{array}$ & $\begin{array}{c}\text { Acces } \\
\text { sibilit } \\
y\end{array}$ \\
\hline \multirow[t]{2}{*}{1} & \multirow[t]{2}{*}{$\mathrm{ADA}$} & Mean & 2.05 & 1.76 & 1.79 & 2.33 & 1.69 & 1.72 & 2.19 & 1.79 & 1.90 & 1.64 \\
\hline & & $\mathrm{CV}$ & 54.34 & 67.63 & 65.87 & 57.69 & 63.88 & 71.90 & 53.05 & 65.87 & 64.53 & 68.33 \\
\hline \multirow[t]{2}{*}{2} & \multirow[t]{2}{*}{ AFTC } & Mean & 1.60 & 1.40 & 1.53 & 1.20 & 1.40 & 1.53 & 1.07 & 1.47 & 1.40 & 1.33 \\
\hline & & $\mathrm{CV}$ & $\begin{array}{c}107.7 \\
4\end{array}$ & 92.74 & 95.04 & 95.54 & 92.74 & 81.26 & 103.10 & 92.44 & 88.72 & 96.82 \\
\hline \multirow[t]{2}{*}{3} & \multirow[t]{2}{*}{ ADE } & Mean & 2.42 & 1.83 & 1.50 & 2.00 & 2.08 & 1.58 & 1.33 & 1.42 & 1.25 & 1.67 \\
\hline & & $\mathrm{CV}$ & 62.28 & 86.50 & 96.40 & 70.71 & 72.24 & 109.25 & 121.07 & 87.54 & $\mid 118.78$ & 78.16 \\
\hline \multirow[t]{2}{*}{4} & \multirow[t]{2}{*}{ ASTE } & Mean & 1.45 & 1.34 & 1.62 & 2.21 & \begin{tabular}{l|l}
1.34 \\
\end{tabular} & 1.34 & 1.45 & 1.38 & 1.48 & 1.55 \\
\hline & & $\mathrm{CV}$ & 89.62 & 89.49 & 83.13 & 79.76 & 03.79 & 105.68 & 87.70 & 89.66 & 101.36 & 88.81 \\
\hline \multirow[t]{2}{*}{5} & \multirow[t]{2}{*}{ CABS } & Mean & 2.71 & 2.36 & 2.36 & 2.64 & 2.50 & 2.43 & 2.79 & 2.93 & 2.57 & 2.43 \\
\hline & & $\mathrm{CV}$ & 52.95 & 56.69 & 48.82 & 43.54 & \begin{tabular}{l|}
40.76 \\
\end{tabular} & \begin{tabular}{l|}
35.07 \\
\end{tabular} & 28.78 & 24.93 & 45.03 & 38.61 \\
\hline \multirow[t]{2}{*}{6} & \multirow{2}{*}{$\begin{array}{l}\text { EEMI } \\
\text { LAC }\end{array}$} & Mean & 1.62 & 1.62 & 1.48 & 1.76 & 1.28 & 1.66 & 1.69 & 1.45 & 1.62 & 1.62 \\
\hline & & $\mathrm{CV}$ & 98.13 & 84.75 & 94.73 & 99.25 & \begin{tabular}{|l|}
106.60 \\
\end{tabular} & 85.86 & 93.72 & 98.66 & 84.75 & 81.48 \\
\hline \multirow[t]{2}{*}{7} & \multirow{2}{*}{$\begin{array}{c}\mathrm{C}- \\
\mathrm{MMA} \\
\mathrm{CS}\end{array}$} & Mean & 1.83 & 17 & 1.17 & 17 & 2.00 & 1.50 & 1.83 & 1.67 & 2.67 & 2.00 \\
\hline & & $\mathrm{CV}$ & $\begin{array}{c}100.0 \\
8\end{array}$ & 100.20 & $\begin{array}{c}100.2 \\
0\end{array}$ & 4.21 & 63.25 & 101.11 & 93.95 & 72.66 & 30.62 & 77.46 \\
\hline \multirow[t]{2}{*}{8} & \multirow[t]{2}{*}{ DARE } & Mean & 1.78 & 2.67 & 1.78 & 2.56 & 2.78 & 2.67 & 2.78 & 2.11 & 2.11 & 2.56 \\
\hline & & $\mathrm{CV}$ & $\begin{array}{c}104.4 \\
0\end{array}$ & 45.93 & 67.60 & 52.17 & 24.00 & 45.93 & 43.27 & 55.26 & 49.93 & 34.51 \\
\hline 9 & LRDE & Mean & 1.50 & 1.00 & 1.00 & 1.50 & 2.00 & 0.50 & 2.00 & 0.50 & 1.50 & 2.00 \\
\hline \multirow{3}{*}{$\mathbf{S} \mathbf{N}$} & \multirow{3}{*}{$\begin{array}{c}\text { Organ } \\
\text { ization } \\
\mathrm{s}\end{array}$} & & \multicolumn{10}{|c|}{ Disadvantages } \\
\hline & & $\begin{array}{l}\text { Iean } \\
\text { and } \\
\text { CV }\end{array}$ & $\begin{array}{l}\text { Slow } \\
\text { downl } \\
\text { oad }\end{array}$ & ime s & $\begin{array}{l}\text { Navig } \\
\text { ation }\end{array}$ & $\begin{array}{c}\text { Additio } \\
\text { nal } \\
\text { Paymen } \\
\text { t }\end{array}$ & \begin{tabular}{|c|} 
Proble \\
ms \\
with \\
print \\
faciliti \\
es in \\
databa \\
ses \\
\end{tabular} & \begin{tabular}{|l|} 
\\
Insecu \\
rity of \\
Preser \\
vation
\end{tabular} & f $\begin{array}{c}\text { Depen } \\
\text { dence } \\
\text { on } \\
\text { connec } \\
\text { tivity }\end{array}$ & $\begin{array}{c}\text { Qualit } \\
\text { y of } \\
\text { print } \\
\text { images } \\
\text { is low }\end{array}$ & $\begin{array}{c}\text { It is } \\
\text { difficul } \\
t \text { to } \\
\text { read } \\
\text { on } \\
\text { screen }\end{array}$ & $\begin{array}{c}\text { Acces } \\
\text { sibilit } \\
y\end{array}$ \\
\hline & & $\mathrm{CV}$ & 47.14 & 141.42 & $\begin{array}{c}141.4 \\
2\end{array}$ & 47.14 & 0.00 & 141.42 & 20.00 & 141.42 & 141.42 & $\begin{array}{c}141.4 \\
2\end{array}$ \\
\hline 10 & GTRE & & & & 1.90 & & & 1.76 & & & 2.76 & 2.24 \\
\hline & & $\mathrm{CV}$ & 57.70 & 61.58 & 57.28 & 42.69 & 58.09 & 80.07 & 762.97 & 59.46 & 44.20 & 48.75 \\
\hline 11 & HAL & Mean & 2.20 & 1.55 & 1.59 & 1.70 & 1.66 & 1.60 & \begin{tabular}{|l|l|}
0.84 \\
\end{tabular} & 1.72 & 1.71 & 1.65 \\
\hline & & $\mathrm{CV}$ & 66.56 & 81.94 & 77.61 & 87.09 & 82.04 & 82.39 & 979.37 & 75.48 & 80.49 & 80.86 \\
\hline 12 & IAM & $\mathrm{Mea}$ & 1.8 & 1.55 & 1.6 & 2.36 & 2.18 & 1.88 & \begin{tabular}{l|l}
8 & 1.88 \\
\end{tabular} & 1.79 & 1.88 & 1.88 \\
\hline & & & 73.80 & 84.20 & 83.74 & 67.58 & 65.28 & 76.16 & 678.45 & 9 & 81.76 & 66.21 \\
\hline 13 & ISRO- & Mean & 2.09 & 9 & 2.00 & 2 & 1.91 & 1.91 & 12.55 & .00 & 2.73 & 2.14 \\
\hline & $\begin{array}{c}\text { ISTRA } \\
\text { C }\end{array}$ & $\mathrm{CV}$ & 65.86 & 96.33 & 69.01 & 47.27 & 82.28 & 85.40 & 555.20 & 77.15 & 50.83 & 65.08 \\
\hline 14 & IISc & Mean & 1.62 & 1.26 & 1.24 & 1.88 & 1.35 & 1.44 & \begin{tabular}{|l|l|}
4 & 1.79 \\
\end{tabular} & 1.47 & 1.68 & 1.62 \\
\hline & & $\mathrm{CV}$ & 62.77 & 83.29 & 69.21 & 66.38 & 65.31 & 72.86 & \begin{tabular}{l|l}
6 & 64.04
\end{tabular} & 77.14 & 86.53 & 80.55 \\
\hline 15 & NCA & Mean & 1.00 & 1.00 & 4.00 & 1.00 & 1.00 & 2.00 & \begin{tabular}{|l|l|}
0 & 1.00
\end{tabular} & 3.00 & 2.00 & 1.00 \\
\hline & SR & $\mathrm{CV}$ & 0.00 & 0.00 & 0.00 & 0.00 & 0.00 & 0.00 & 0.00 & 0.00 & 0.00 & 0.00 \\
\hline 16 & NAL & Mean & 2.21 & 1.60 & 1.63 & 1.94 & 1.51 & 1.50 & \begin{tabular}{|l|l|}
0 & 1.94 \\
\end{tabular} & 1.79 & 2.25 & 1.98 \\
\hline & & $\mathrm{CV}$ & 53.87 & 80.14 & 77.89 & 76.15 & 80.74 & 85.00 & 668.72 & 68.38 & 57.07 & 65.37 \\
\hline & $\frac{1}{\text { Mean }}$ & Mean & 2.07 & 1.60 & 1.64 & 2.02 & 1.67 & 1.63 & \begin{tabular}{|l|l|}
3 & 1.93 \\
\end{tabular} & 1.74 & 1.97 & 1.81 \\
\hline & $\begin{array}{l}\text { Scores } \\
\text { btained } \\
\text { for } \\
\text { sadvanta } \\
\text { es of e- } \\
\text { ournals }\end{array}$ & $\mathrm{CV}$ & 65.59 & 79.57 & 76.43 & 73.65 & 77.21 & 1.10 & 071.50 & 2.58 & 69.83 & 71.08 \\
\hline $\mathrm{PV}$ & Values & & 0.035 & 0.251 & 0.278 & 0.004 & 0.003 & 0.223 & 30.006 & 0.048 & 0.000 & 0.128 \\
\hline
\end{tabular}




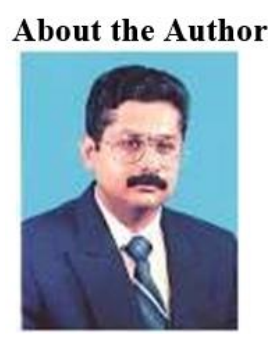

Dr Ramachandran Guruprasad is a Scientist at the CSIR-National Aerospace Laboratories, Bangalore, INDIA. He received his MLIS degree from Annamalai University (1994), MSc in Information Technology from Karnataka State Open University (2006) and a Ph.D. Degree in Library and Information from the University of Mysore (2010). He has two international books to his credit, several book chapters, international conference presentations and national and international journal publications. His areas of interest and specialization include: analyzing the 'Use Patterns of Electronic Information Resources among Scientists, Engineers and Technologists', 'Digital Content Management', 'Digital Video Archiving'. He is the recipient of three national awards, namely: (a) Education ExpoTV (EET-CRS), Special Mention Certificate in the Category of 'Excellence in Research', (b) 'Scientist of the Year 2013' from the National Environmental Science Academy (NESA), New Delhi and (c) Education ExpoTV (EET-CRS) 'Award for Excellence in Technology Research' in the category of Technology Leadership Awards. 